\title{
The efficacy and safety of add-on $0.1 \%$ brimonidine tartrate preserved with sodium chlorite in on-treatment Japanese normal-tension glaucoma patients [Corrigendum]
}

\author{
Tsumura T, Yoshikawa K, Kimura T, et al. Clin Ophthalmol. \\ 2014;8:1681-1687.
}

The authors wish to advise of the following errors: on page 1684 , right column, line 18 , "10.72" should be replaced with “-10.72"; on page 1685 , right column, line 2, “ $<-6 \mathrm{D}$ ” should be replaced with " $<-6 \mathrm{~dB}$ ". covering all subspecialties within ophthalmology. Key topics include: Optometry; Visual science; Pharmacology and drug therapy in eye diseases; Basic Sciences; Primary and Secondary eye care; Patien Safety and Quality of Care Improvements. This journal is indexed on

PubMed Central and CAS, and is the official journal of The Society of Clinical Ophthalmology (SCO). The manuscript management system is completely online and includes a very quick and fair peer-review system, which is all easy to use. Visit http://www.dovepress.com/ testimonials.php to read real quotes from published authors 